\title{
The U.S. Gun-Control Paradox: Gun Buyer Response To Congressional Gun-Control Initiatives
}

Michael A. Jones, Ph.D., Southeastern Louisiana University, USA George W. Stone, Ph.D., North Carolina A\&T University, USA

\begin{abstract}
Many scholars and interest groups in the U.S. advocate for more gun-control in terms of restrictions on sales. Following the Sandy Hook shooting in Newtown, Connecticut in December 2012, The Obama Administration initiated legislation to restrict gun sales. Coincidentally, U.S. firearm sales surged to record levels and ammunition shortages occurred. This article examines the gun control issue in the U.S. in light of the events of 2013, demonstrating the paradox which gun-control advocates face. The authors provide background information on the gun-control debate including the social cost of gun-violence and the U.S. political battle over the issue.
\end{abstract}

Keywords: U.S. Gun-Control Paradox; Gun-Control Debate; Congressional Gun-Control Initiatives

\section{INTRODUCTION}

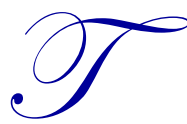

his study examines the response of US firearm and ammunition consumers to the Obama Administration's 2013 initiative to pass new gun control legislation. After staying-clear of guncontrol during his first term, President Obama initiated a dialog proposing the need for new gun control legislation after the Sandy Hook Elementary tragedy in December 2012 (McWhinnie 2013). What followed was a sharp increase in gun sales and a run on ammunition which lead to stock-outs, shortages and rationing (Kesling 2012, Plumer 2012) NICS (National Instant Criminal Background Check System) checks, which are seen as a proxy for firearm sales, increased nearly $60 \%$ during the first 6 months of 2013. Ammunition sales spiked during the same period of time, leading to stock-outs and rationing. Record sales and profits for U.S. firearms and ammunition manufacturers and retailers were reported in 2013, and the NRA (National Rifle Association) has indicated its membership increased to a new record 5 million members (Korte 2013).

Thus, while trying to initiate new legislation which would restrict gun sales to consumers, the administration's proposed legislation resulted in more "guns on the street." Ironically, the U.S. firearm industry aggressively opposed the Obama Administration in both of its elections. This paradox presents a dilemma for any U.S. Presidential Administration trying to impose restrictions on firearms, but particularly for a Democratic administration. Though the restrictions have been imposed upon many products in the past century by the Federal Government, it appears that firearms are among the most sensitive to regulatory threats based on U.S. gun consumers' response. This article outlines the events of 2012-2013, and the response of the U.S. consumer gun market to those events. Societal concerns associated with guns-violence are discussed by the authors, along with issues regarding firearm retailing in the U.S. An overview of the major lobbies involved in the political battle over gun-control is provided as well. The article does not take a political or philosophical position on the current legality of the production and sale of guns in the U.S.

\section{THE U.S GUN CONTROL ISSUE}

The debate associated with the restriction and accessibility of firearms is among the most heated and contested in U.S. society (Bradford 2013, Chemerisnsky 2004). The debate stems from the interpretation of the 
Second Amendment, which grants citizens of the United States the right to bear arms. Those who embrace it believe that the right to bear arms is an absolute right, and that efforts to limit the ability to purchase, possess, or carry firearms are unnecessary (Utter and True 2000).

At the center of the debate surrounding firearm sales in the U.S., is gun violence, a problem that is a major societal threat to human life and health in the U.S. (Bradford, et.al. 2005, Murphy and Sherry 2013). Statistics on injury and death from, and the social cost of gun violence in the U.S. are sobering. According to the Firearm Injury Center at The University of Pennsylvania:

- $\quad$ Firearm deaths in the United States average 32,300 per year from 1980 to 2006, or about 88 per day.

- $\quad$ Firearm are the second leading cause of death from injury after motor vehicle crashes

- $\quad$ One person every 5 minutes is treated for firearm injuries in US emergency rooms.

In terms of economic costs, it is estimated that the annual cost from firearm violence in the US exceeds $\$ 100$ Billion (Cook and Ludwig 2001). A wide variety of indirect costs have been attributed to firearm violence including: expenses on increased security, loss of business in certain locations, increased insurance costs, loss of productivity due to sick days, and pain and suffering. According to the Children's Defense Fund (2012), six times as many U.S. children and teens $(35,000)$ suffered non-fatal gun injuries as gun deaths in 2008 and 2009. The US Department of Justice estimates that nearly 500,000 U.S. citizens annually are victims of crimes committed by firearms (about 1 per minute).

A major factor in the gun control debate is how the United States compares to other industrialized nations with regard to violence and firearm death rates. Richardson and Hemmingway (2011) concluded that gun-related homicide rates in the United States is at least 19 times higher than 23 other "high income" countries. Children in the United States under 15 years of age die of gunshot wounds at a rate 12 times higher than children from 25 other industrialized nations (Krug et al. 1998).

\section{The Number Firearms in the US}

Another issue in the debate over gun-control in the United States is related to the number of guns owned by individuals in the United States, which is the highest in the world both in per capita and total numbers. The concern stems from a number of studies which have shown that as gun ownership increases so does firearm homicide, both on a country- to- country basis, and on a state- by- state basis (Penn Center 2012, Seigel et al 2013). But, measuring gun ownership among the population is complex for obvious reasons and estimates often vary significantly. Historically, gun ownership among rural farming families was commonplace by necessity, and those guns have been both accumulated and passed-down for generations. The Federal Government estimates there are 310,000,000 individually owned guns in the United States owned (Sanburn 2012). A recent major study using multiple sources of data estimated that 51.7 percent of individuals in the United States owned guns in 2010 (Seigel et al 2013). The same study estimated that Hawaii ranked at the bottom in terms of individual gun ownership ( $25 \%$ gun ownership) while Mississippi ranked first in gun ownership at $76.8 \%$. Recent surveys citing self-reported gun ownership in the United States (Gallup, The University of Chicago General Social Survey) found somewhat lower levels ranging between 32 to 47 percent.

\section{A Central Marketing Issue: Diversion in Retail Distribution}

Most of the political battles over gun-control center on the issue of consumer access to firearms and the legal distribution of firearms. While Federal laws prescribe who can sell firearms, how they may be sold, the type of guns that may not be sold, and the types of customers who are allowed to buy them, many researchers have identified problems with the distribution system now in place in the United States (Bradford 2005). A major issue is diversion, defined as "any movement of firearms from the legal to the illegal marketplace through an illegal method or for an illegal purpose" (Gundlach 2010). Although most gun buyers in the United States buy from federally licensed retail dealers, a small proportion of illegal dealers account for thousands of diverted firearms annually (Koper 2007). According to several studies, the large number of federally licensed gun retailers complicates the control of diversion (Gundlach 2010, Brady Center 2007). For comparison's sake, while there are 65,000 federally 
licensed dealers in the United States, there are only 36,569 grocery stores (Food Marketing Institute 2011) and 14,098 McDonald's Restaurants (McDonald's Annual Report 2012). Other significant sources of unauthorized firearm sales include unlicensed street dealers, sales of stolen guns, and firearms purchases between individuals that go unreported (ATF 2012). There are 4,000 advertised gun shows in the United States annually.

\section{THE POLITICAL “BATTLE” OVER GUN CONTROL: THE LOBBIES}

The difficulty experienced by the Obama Administration in passing anti-gun legislation is attributed to an increasingly powerful "gun lobby" in the US. It should be noted, however, that the passage of laws restricting gun sales to individuals in the United States is not a new issue. Beginning with the National Firearms Act of 1934, a series of 10 major Federal laws controlling individual firearm sales have been passed, with the majority of the laws enacted during the 1980's and 1990's. Nevertheless, the political environment surrounding US gun legislation has become increasingly divisive in recent years (Chemerinsky 2004) as more and more professional lobbying groups, representing both sides of the gun ownership issue, now routinely join in heated, often highly contentious debates before Congress. As seen in Figure 1, the pro-gun lobby, widely acknowledged to be the more powerful voice in the debate, outspent the gun-control lobby by a ratio of $23: 1$ in 2011 , or $\$ 5.5$ million versus $\$ 240,00$ (OpenSecrets.org 2012).

The National Rifle Association (NRA), with over 5 million members and revenues in excess of \$200 million/year, is the largest of the pro-gun lobbying organizations (Kortz 2013, National Rifle Association). The group's 2013 meeting in Houston had 80,000 attendees. The NRA embraces the "slippery slope argument," which espouses that a small first step in changing a law leads to a chain of related events resulting in a significant effect (Utter and True 2000). Referred to as a "very effective and powerful lobby" by many, the NRA is well-organized and quite active in local, state and national elections, spending millions of dollars annually.

Figure 1. 2010 Expenditures by gun-issue nonprofits
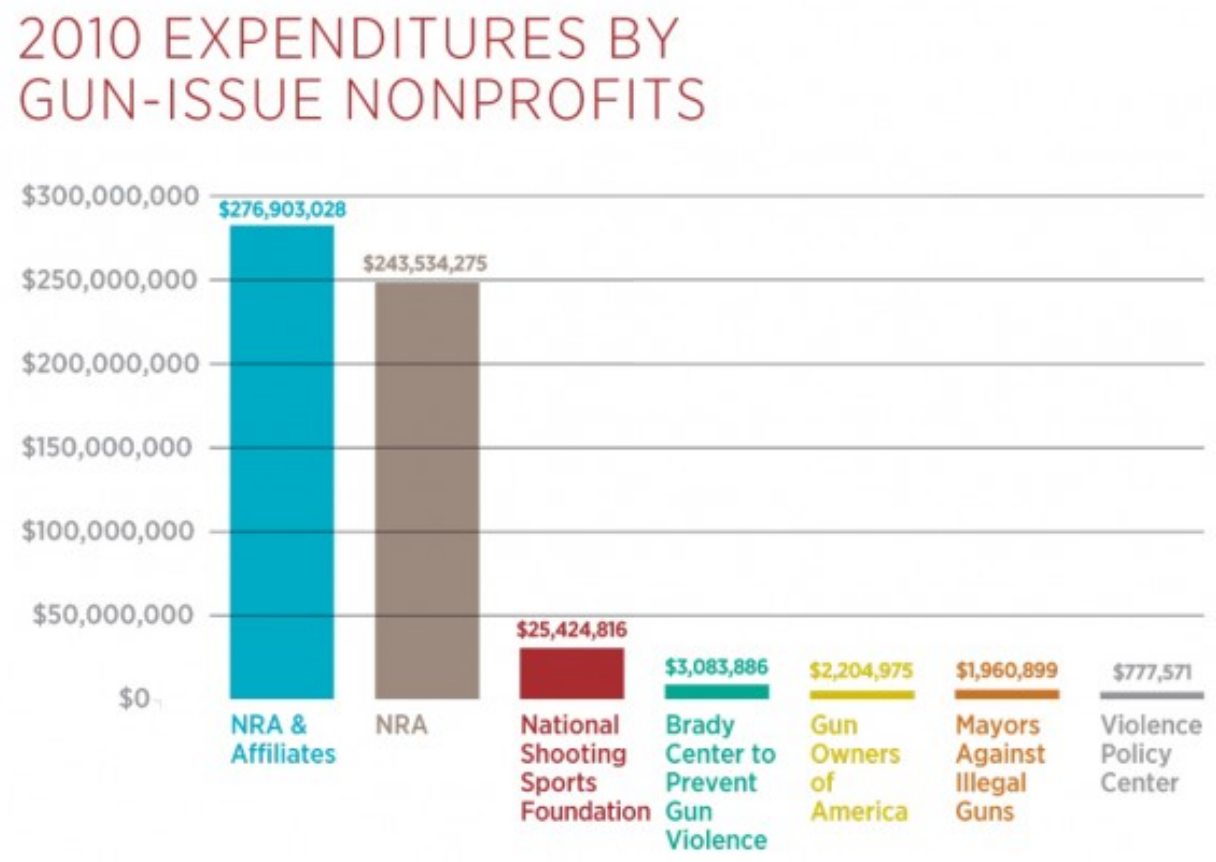

Source: IRS 990 tax forms for 2010. The affiliates of the NRA include the NRA Foundation [2010 expenditures: \$26,539,658], NRA Freedom Action Center [\$2,541,434], NRA Civil Rights Defense Fund [\$749,265] and NRA Special Contribution Fund [\$3,538,396].)

For example, in September 2013, the NRA spent over $\$ 400,000$ in a single Colorado State Senate election race to successfully defeat two established senators. These two Senators had recently voted for a Colorado bill 
providing for universal background checks and limiting assault rifle magazines to 15 rounds (Caldwell 2013). One of those senators was the current President of the Colorado Senate. Wayne LaPierre, the NRA's CEO and its top lobbyist, is paid almost $\$ 1$ million/year, and is widely admired for his skill and effectiveness at lobbying (Plumer 2012).

Regardless of the power wielded by the NRA, it is not the only pro-gun lobbyist Group, nor is it considered the most conservative. The Gun Owners of America and the Second Amendment Sisters are two well-funded gun lobbying groups that have managed to achieve rapid ascendancy among pro-gun advocates in recent years. The 300,000 member Gun Owners of America (GOA), for example, spent \$1,307,000 lobbying politicians in 2012 alone (Open Secrets 2012).

While it might be assumed that firearm manufacturers and pro-gun advocacy groups share the same political objectives, this is not always the case. The firearms manufacturing industry often finds itself at odds with the NRA and other conservative pro-gun lobbying groups and has therefore formed its own lobbying group, The National Shooting Sports Foundation (NSSF). This organization represents the interests of gun manufacturers, as well as the nearly 8,000 wholesale and retail firearms dealers.

Although anti-gun advocates are undermanned and underfunded in comparison to their pro-gun lobby counterparts, the Brady Campaign to Prevent Gun Violence and the Coalition to Stop Gun Violence are two powerful organizations known to support gun control (Garret 2012). Both groups are active in national, state and local politics, and have been successful in promoting grass-roots campaigns to promote their cause. The Coalition to Stop Gun Violence is comprised of 47 national organizations, including professional medical associations (such as the American Pediatrics Association), faith-based groups, child welfare advocates, public health professionals, and social justice organizations. The level of political support in Washington for the anti-gun lobby reached its height in the years following the assassination attempt on President Reagan. Their efforts lead to the passage of the Brady Bill (1993), which was soon followed by the Assault Weapons Ban in 1994 and the Gun Free School Zones Act in 1995.

\section{THE EVENTS OF 2013}

Seizing the opportunity created by the December 14, 2012 Sandy Hook school shooting, President Obama and Vice President Joe Biden proposed a list of executive actions directed at stronger gun control in January 2013. Legislation was introduced in Congress to ban military-style assault weapons and ammo capacities of more than 10 rounds, and impose background checks on all gun sales. The senate voted 54-46 to expand background checks only, but fell short of the 60 votes needed to stop a filibuster---primarily because Democratic senators from the so called rural "gun states" would not support the bill. According to Weisman (2013) the bill's fate was sealed by the same party-line divisions in Congress that have prevailed on Capitol Hill in recent years. Weisman goes on to state that the bill faced several obstacles including deep ideological and regional divides and the lopsided power of the NRA.

\section{US Gun Sales}

Based upon NCIS Background checks, 2013 was a record year, with 21,093,273 background checks being performed, as seen in Figure 2. Background checks in 2013 represented an 8 percent increase over 2012, and almost doubled the number conducted in 2007. In descending order the three highest months on record for background checks were: December 2012, January 2013 and February 2013.

While Texas and Kentucky led the nation in background checks during this period, background checks alone do not adequately indicate how many guns are sold in the US in any given year (Rogers 2012) since not every background check leads to a gun purchase. Further, many private sales by individuals or at gun shows are not recorded. Also, most US firearm manufacturers are privately held, and thus do not report sales. The true figure is clouded even more by the lack of a precise figure on the number of guns imported each year. Hence, while actual annual gun sale figures are little more than a rough estimate, what appears clear is that gun sales have risen steadily since 2004---and the rate of increase has been even higher since President Obama's 2008 election. 2013 was a record year for the US gun industry by many measures: sales, production and profits are among those. 
Figure 2. Total NICS Background Checks

\begin{tabular}{llc}
\multicolumn{3}{c}{ November 30, 1998 - March 31, 2014 } \\
\hline 1998 & 892,840 \\
1999 & $9,138,123$ \\
2000 & $8,543,037$ \\
2001 & $8,910,191$ \\
2002 & $8,454,322$ \\
2003 & $8,481,588$ \\
2004 & $8,687,671$ \\
2005 & $8,952,945$ \\
2006 & $10,036,933$ \\
2007 & $11,177,335$ \\
2008 & $12,709,023$ \\
2009 & $14,033,824$ \\
2010 & $14,409,616$ \\
2011 & $16,454,951$ \\
2012 & $19,592,303$ \\
2013 & $21,093,273$ \\
2014 & $6,236,060$
\end{tabular}

Source: $h t t p: / / w w w . f b i . g o v / a b o u t-u s / c j i s / n i c s / g e n e r a l-i n f o r m a t i o n / f a c t-s h e e t$

It should be noted that even though 2013 was a record year for the US gun industry, heavy buying of guns actually started immediately following the Sandy Hook tragedy in December 2012. Firearm sales tend to spike after mass shootings, but Sandy Hook sparked a new record in activity. An all- time record 953,613 NCIS Background checks were performed during the week of December 17-23. The figure is 50 percent higher than the next highest week ever recorded. Friday, December 21 was the all-time record day for background checks at over 177,000. Many attribute those high sales to anticipation of gun control legislation expected as a result of the Sandy Hook incident (Kesling 2012). An estimated 120,000-130,000 guns were sold on the Saturday after the shooting (Chaddock 2013).

During 2013, US gun makers were not able to keep pace with the strong surge in demand. For the 2013 fiscal year ending April 30, Smith and Wesson, the largest publically traded US gun maker, reported gun sales of $\$ 588$ million. In addition to being the highest level of sales ever recorded by the company, the $\$ 500$ million figure represented a 43 percent rise year over the previous year (Douglas 2013). Further, the company's backlog of orders totaled $\$ 877$ million, more than double the back orders from a year earlier. Sturm Ruger, the nation's second largest gun maker, reported $2^{\text {nd }}$ quarter 2013 sales to be up by 50 percent from the previous year and its backlog climbed 600 percent in the first quarter of 2013, to 2.1 million orders. Stag Arms, a small maker of AR-15 Rifles doubled production from 2012 to 2013 (Pompa 2013). Back orders for 70,000 more AR-15s will take 2 years for the company to fill.

Retailers of guns in the US had a banner year in 2013 too. Although sales information is difficult to obtain since most gun retailers are small, privately owned stores, there were- widely reported accounts of strong retail sales during 2013. A spike in sales occurred in December 2012, immediately after the Newtown shooting, with strong retail sales of firearms were reported from "gun-friendly states" in particular. For example, retail gun purchases in Utah during the first quarter of 2013 doubled the average first quarter sales for the prior decade (Kennedy 2013). Utah's Bureau of Criminal Identification reported new records for the number of applications for concealedweapons permits during the first quarter of 2013, causing employees to work overtime until more could be hired. While most large national retailers of guns (e.g., such as Walmart and Cabelas) do not report individual level gun sale revenue, Walmart, the nation's largest seller of guns reportedly increased gun sale revenue by 76 percent in the first half of 2013. Stock-outs of assault rifles were reported at Walmart stores in five states. One small retailer in North Caroline, which had been in business since 1976, reported sales of over $\$ 1,000,000$ during one Saturday following Sandy Hook. 


\section{US Ammunition Sales}

The market for ammunition in 2013 was even more chaotic than the market for guns, with widespread shortages of ammunition being reported among retailers and consumers. Like gun manufacturing, the U.S. ammunition making industry is privately held making statistics on U.S. ammunition sales are difficult to obtain (Jones 2013). Certain sizes of bullets became very scarce during early 2013 causing stock-outs among retailers (Smith 2013). Rumors and speculation about the lack ammunition were widespread according to industry sources (Adelmann 2014). According to one industry analyst, all of the major ammunition makers increased production to "seven days" week plus overtime during March 2013. Walmart, also the world's largest seller of ammunition, actually rationed ammunition in February 2013 by limiting individual purchases to 3 boxes (Smith 2013). In March 2013, Black Hills Ammunition, a maker of bullets in South Dakota, was quoting delivery times on orders for January 2014, meaning that it would take them nine months to catch-up with demand (Jones 2013).

One situation which was not anticipated was the unavailability of ammunition for local law enforcement agencies for training and qualifying on particular weapons. Supplies became so low that many city police and sheriff's departments had to suspend firearms training and practice at firing ranges. Related products and supplies such as magazines and re-loaders also experiences stocks outs and shortages, prompting speculation that re-loaders would not be available for 6-9 months (Adelmann 2013).

\section{CONCLUSION}

Gun control is a complex and controversial issue among many Americans, as there are strongly held beliefs on both sides of the gun rights issue. Ironically, in 2013, the U.S. firearms industry benefited from an Administration that the NRA and the industry had fiercely opposed in both the 08 and 12 elections. One can conclude that the U.S. firearm/ammunition consumer market is quite sensitive to threats of Government action to limit perceived Second Amendment rights, particularly from a Democratic Administration.

Many citizens, interest groups, scholars and professionals in fields such as health care feel the U.S. has a problem with availability of guns, and thus support laws which would place more limits on gun sales. However, based upon the events of 2012-2013 outlined above, changes in the Federal law which would limit or restrict gun sales do not appear probable in the near term. Should a Republican win the White House in 2016, one would assume that gun-control at the Federal level would not be a part of that administration's agenda. Cause-oriented marketing efforts, as well as political initiatives by gun-control advocates in the U.S. face a paradox: the more advocates push for increased regulation to limit gun sales, the more guns that are sold.

\section{AUTHOR INFORMATION}

Michael A. Jones, Ph.D., has his B.A. and M.S. from Louisiana State University and his Ph.D. from the University of Missouri. Southeastern Louisiana University, P.O. Box 10844, Hammond, LA 70402 USA. Email: mijones@selu.edu

George W. Stone, Ph.D., has his BS from the United States Military Academy, M.S. from Boston University, and his Ph.D. from the University of Mississippi. Dr. Stone's research interests include Ecological/Green Marketing, Industrial Marketing, and Political Advertising. North Carolina A\&T University, Marketing Department 310 Merrick Hall, Greensboro, NC 27411 USA. Email: gwstone@ncat.edu 


\section{REFERENCES}

Adelmann, Bob. “Ammo Shortages: More than Simple Supply and Demand?" The New American. The New American, 8 Mar. 2013. Web. 25 Feb. 2014.

Adelmann, Bob. "DHS Spokesman Waffles over Huge Ammo Purchases." TheNewAmerican. The New American, 26 Apr. 2013. Web. 25 Feb. 2014.

ATF. "Federal firearms license statistics, theft/loss reports" ATF. Bureau of Alcohol, Tobacco, Firearms and Explosives, Office of Strategic Intelligence and information, 12 Jan. 2014. Web. 2 Feb. 2014.

ATK. "A Letter to Customers" Federalpremium. ATK Sporting Group, 28 Apr. 2013. Web. 25 Feb. 2014.

Bradford, Kevin D., Gundlach, Gregory T., and Wilkie, William L. (2013) "Countermarketing and Demarketing Against Product Diversions: Forensic Research in the Firearms Industry," Journal of Public Policy and Marketing, 29 (Spring), 103-122.

Bradford, Kevin D., Gundlach, Gregory T., and Wilkie, William L.(2005) "Countermarketing in the courts: the case against marketing channels and firearm diversion," Journal of Public Policy and Marketing, 24 (Spring), 284-298.

Benko, Ralf. "1.6 Billion Rounds of Ammo for Homelands Security? It's time for a National Conversation.” Forbes. Forbes, 11 Mar. 2013. Web. 2 Feb. 2014.

Caldwell, Leigh A. "Colorado recall election prompts gun debate," CNNPolitics. CNN, 11 Sept. 2013. Web. 25 Feb. 2014.

Chaddock, Gail R. "Gun lobby: Congress doesn't have the muscle to pass gun control." CSMonitor. Christian Science Monitor, 13 Jan. 2013. Web 25 Feb. 2014.

Chemerinsky, Erwin. (2004) "Putting the Gun Control Debate in Social Perspective," Fordham Law Review, 73 (2) $1-11$.

Cook, Phillip J. and Ludwig, Jens. "Toward smarter a gun control laws”. CSMonitor. Christian Science Monitor, 06 Feb. 2001. Web. 02 Feb. 2014.

Date, Jack. "Guns in America, a Statistical Look" ABC News. ABC, 25 Aug. 2014. Web 2 Feb. 2014.

Davilla, Joseph. "Newtown Gun Permits Surge.” WSJ. The Wall Street Journal, 1 Aug. 2013. Web. 2 Feb. 2014.

Douglas, Craig. "Bring the Boom: Smith \& Wesson Guns for Big Growth as Sales Hit Record Levels." BizJournals. Boston Business Journal, 27 June 2013. Web. 2 Feb. 2014.

Garrett, Ben. "Political shootings and restricted gun rights: the effect of high profile political on new gun control law," Civil liberty.about. About, n.d. Web. 25 Feb. 2014.

Gundlach, G, Bradford, K. and Wilkie, W. (2010) "Countermarketing and Demarketing against product diversion: forensic research in the firearms industry," Journal of Public Policy and Marketing, Vol 29 (1) Spring 2010, 103-122.

Hawkins, AWR. “Ammo Manufacturers Producing '24 Hours a Day' to Match Demand” Ammoland. Ammoland Shooting Sports News, 08 Apr. 2013. Web. 2 Feb. 2014.

Rogers, Simon. "How many guns are sold in the US?" The Guardian. The Guardian News, 17 Dec. 2012. Web. 2 Feb. 2014.

Hawkins, A.W.R. "DHS Ammo Purchases: Gun Control By Another Name?" Breitbart. Breitbart News Network, 10 Feb. 2013. Web. 2 Feb. 2014.

Hornady "A Word on Availability” Hornady. Hornady Manufacturing, 12 Nov. 2013. Web. 2 Feb. 2014.

Infomine. "Historical Copper Prices and Price Chart". Infomine. Investment Mine Mining Intelligence Community, 31 Dec. 2013. Web. 2 Feb. 2014.

Johnson, Kevin. "Firearms Debate: Meet the Gunmakers." USAToday. USA Today, 27 Feb. 2013. Web. 2 Feb. 2014.

Jones, Ashby. "Bullet Run Leaves Many Low on Ammo." WSJ. The Wall Street Journal, 28 Feb. 2013. 2 Feb. 2014.

Kennedy, Bruce. "Will 2013 Mark Record Gun Sales in U.S.” MSN. MSN Money, 19 Jul. 2013. 2 Feb. 2014.

Kesling, Ben. "Fear of New Restrictions Drives Crowds to Gun Shows." WSJ. The Wall Street Journal. 24 Dec. 2012. Web. 25 Feb. 2014.

Koper, Christopher S. "Crime Gun Risk Factors: Buyer, Seller, Firearm, and Transaction Characteristics Associated with Gun Trafficking and Criminal Gun Use” Philadelphia, PA. Jerry Lee Center of Criminology, 2007. Print.

Korte, Gregory. "Post-Newtown, NRA Membership Surges to 5 Million.” USAToday. USA Today, 4 May 2013. Web. 25 Feb. 2014. 
Krug, EG, Dahlberg LL, Powell KE. "Firearm-related deaths in the United States and 35 other high and upper middle income countries," International Journal of Epidemiology, 27:214-21.

Martinelli, Michelle and Merlin, Michelle. "Gun rights lobbying" OpenSecrets. Open Secrets Center for Responsive Politics, 14 Dec. 2014. Web. 2 Feb. 2014.

McWhinnie, Eric. "Obama's Gun Control Efforts Boosts Firearm Sales.” USAToday. Wall St. Cheat Sheet, 1 Aug. 2013. Web 25 Feb. 2014.

Murphy, Patrick. E. and Sherry John F. Ed. "Marketing and the Common Good: Essays from Notre Dame on Societal Impact.” London. Taylor \& Francis Ltd, 2013. Print.

NICS. "NICS Firearms Checks: Top 10 Highest Days/Weeks November 30, 1998 - March 3, 2013." FBI. National Instant Criminal Background Check System, 31 Mar. 2013. Web. 2 Feb. 2014

Open Secrets.Org: Center of Responsible Politics "Gun rights lobbying," available at http://www.opensecrets.org/lobby/indusclient.php?id=q13\&year=2011. Accessed December 2013.

O'toole, James. "Smith \& Wesson booked record sales as gun debate raged." CNN. CNN Money, 13 June. 2013 Web. 2 Feb. 2014.

NSSF. "December 2012 NSSF NICS-Adjusted Background Checks Up 58.6 Percent." NSSF. National Shooting Sports Foundation, 28 Apr. 2013. Web. 2 Feb. 2014.

Peacock, Nelson. "Dr. Coburn Releases Correspondence with DHS Regarding Ammunition Purchases." HSGAC. U.S. Senate Committee on Homeland Security \& Governmental Affairs, 2 Apr. 2013. Web. 2 Feb. 2014.

Plumer, Brad. "How the U. S. Gun Industry Became So Lucrative." Washingtonpost. The Washington Post. 18 Dec. 2012. Web. 25 Feb. 2014.

Pompa, Frank. "U.S. Firearms and Ammunition Production Surges to All-Time High," USAToday. USA Today, 27 Feb. 2014. Web. 25 Feb. 2014.

Richardson, E.G. and Hemmingway, D. (2011) "Homicide, suicide and unintentional firearm fatality: Camparing the United States with other high-income countries, 2003," Journal of Trauma-Injury Infection \& Critical Care, 70 (1) 238-43.

Rogers, Simon. "How Many Guns are Sold in the U.S." TheGuardian. The Guardian News Network, 17 Dec. 2012. Web. 2 Feb. 2014.

Sanburg, Josh. “America's Gun Economy by the Numbers.” Time. Time Publishing, 18 Dec. 2012. Web. 2 Feb. 2014.

Siegel, M., Ross, C., and King, C. The relationship between gun ownership and firearm homicide rates in the United States, 1981-2010," The American Journal of Public Health, November 13, 2013 Vol. 103, No. 11, 20982105.

Smith, A. "Gun shops face massive ammunition shortage," CNN Money, March 12, 2013.

Stynes, Tess. "Smith and Wesson Earnings: Revenue Rises 38\%." The Wall Street Journal, 25 Jun. 2013. Web. 2 Feb. 2014.

UPenn. "Firearm Injury in the U.S. Pennsylvania: Firearm and Injury Center at Penn" UPHS. University of Pennsylvania, 31 Dec. 2011. Web. 25 Feb. 2014.

Utter, Glenn H., and True, James L. (2000) "The evolving gun culture in America, Journal of American \& Comparative Cultures," Journal of American \& Comparative Cultures 23 (2): 67-69.

Weisman, J. “Senate Blocks Drive for Gun Control,” New York Times, April 17, 2013. 